Essay

\title{
From PKU Online Lessons for Dietetics Students to the PKU Sandwiches Album
}

\author{
Klaudia Konikowska ${ }^{1, *(\mathbb{D})}$ and Renata Mozrzymas ${ }^{2}$ \\ 1 Department of Dietetics, Faculty of Pharmacy, Wroclaw Medical University, 51-616 Wrocław, Poland \\ 2 Research and Development Center, Regional Specialist Hospital, 51-124 Wrocław, Poland; \\ renata.mozrzymas@wssk.wroc.pl \\ * Correspondence: klaudia.konikowska@umw.edu.pl
}

check for updates

Citation: Konikowska, K.; Mozrzymas, R. From PKU Online Lessons for Dietetics Students to the PKU Sandwiches Album. Educ. Sci. 2022, 12, 136. https://doi.org/ 10.3390/educsci12020136

Academic Editors: Eila Jeronen and Gurpinder Singh Lalli

Received: 6 December 2021 Accepted: 14 February 2022 Published: 18 February 2022

Publisher's Note: MDPI stays neutral with regard to jurisdictional claims in published maps and institutional affiliations.

Copyright: (C) 2022 by the authors. Licensee MDPI, Basel, Switzerland. This article is an open access article distributed under the terms and conditions of the Creative Commons Attribution (CC BY) license (https:// creativecommons.org/licenses/by/ $4.0 /)$.

\begin{abstract}
The purpose of the manuscript is to present to academic teachers, doctors and nutritionists how practical online classes with dietetics students can be used to develop ready-made tools at work and for the education of phenylketonuria (PKU) patients and their caregivers/parents. During online classes in 2020, as part of the subject-diet therapy of metabolic blocks, 53 students prepared PKU sandwiches at home. Each PKU sandwich has a calculated nutritional value, and phenylalanine exchanger content, but does not include low-protein bread. The selection of a particular type of PKU bread depends solely on the PKU patient, hence it was deliberately not included in the calculations. The sandwiches, made by students and assessed by academic teachers, will be published with the following title "The PKU Sandwiches Album". The Album with more than 400 colorful pictures of PKU sandwiches, will be expected to inspire patients and help them add appeal to their diet, enriching it with new tastes, at the same time facilitating the memorizing process of ingredients, thanks to visualization and presented calculations, and motivating them to comply with strict dietary recommendation. The same nutritional calculations and ideas for sandwiches, with the use of different bread, e.g., gluten-free, may be useful in other diseases, such as celiac disease.
\end{abstract}

Keywords: phenylketonuria (PKU); phenylalanine (Phe); diet; nutritional education

\section{Introduction}

Without dietary education, there would be no effective nutritional treatment in phenylketonuria (PKU). From the very beginning of newborn PKU screening, dietary education plays a very important role in PKU therapy [1,2]. Patients in different treatment centers around the world have different dietary guides, e.g., "Low protein cookery for PKU", "A diet like from a fairy tale-low-phenylalanine diet" [3,4]. Dietary management along with measures to support a low-phenylalanine diet in patients with PKU varies by country. Even between centers in Europe, significant differences are found [5]. The extent of knowledge of PKU has a role in dietary adherence [6]. Some authors point out the benefits of using a Phenylalanine exchanger (PheE) system. [7,8]. However, there are reports that show that knowledge alone does not always guarantee compliance with therapeutic recommendations in practice, because it may be influenced by other factors, such as, e.g., poor parental educational achievement at school level and unsatisfactory maternal dietary knowledge $[9,10]$. Similarly, in a multi-center study carried out in Poland, it was shown that the knowledge of parents and children about therapeutic recommendations and food products does not have a direct impact on the attitude to the PKU diet, and one of the reasons for the negative attitude to implementing dietary recommendations is limiting children's independence in choosing meals and the shame resulting from the necessity of using a different diet to healthy people [11].

Based on the above, in order to meet the expectations of PKU patients, we focused primarily on the practical aspects of the diet and, as part of the classes at the Wroclaw Medical University, together with dietetics students, we gave the patients ready-made 
solutions in the form of PKU sandwiches, giving them the maximum choice of dishes in this respect along with the calculated nutrition value.

During the 2020/2021 academic year, dietetics students who were in the second year of first-cycle studies at Wroclaw Medical University participated in online classes (except for the first lesson) through the BigBlueButton (BBB) platform, during the COVID-19 pandemic. Having learned from lectures about diet-therapy of rare metabolic diseases such as PKU, LCHADD (long-chain 3-hydroxyacyl-CoA dehydrogenase deficiency) and MSUD (maple syrup urine disease), students applied their knowledge in practice by composing diets in the DietetykPro [12] programme (DietetykPro, Wrocław, Poland) during remote classes. The DietetykPro is an online program for dieticians to compose meals and menus for healthy and sick people, which mainly incorporates Polish Food Composition databases developed at the National Food and Nutrition Institute in Warsaw [13] and the database of the United States Department of Agriculture (USDA) [14]. Additionally, in order to receive credit for their course, they were supposed to make eight PKU sandwiches at home. It constituted both the practical part of the course and a form of dietary education for students of dietetics, originally conceived by us-academic teachers-as dedicated directly to patients with PKU. The sandwiches, made by students and verified by us, will be featured in a publication titled The PKU Sandwiches Album (in polish: Album kanapek PKU).

The manuscript was written for doctors, nutritionists and academic teachers to give them an idea to use the potential of students, which can be used to educate patients in a rare genetic disease such as PKU.

The main purpose of the manuscript is to present how practical online classes with dietetics students can be used to develop ready-made tools for the use of a low-protein diet and dedicated to patients with PKU, such as The PKU Sandwiches Album.

\section{From Online Lessons during the COVID-19 Pandemic to Practical Education in PKU}

In 2020, in remote classes held during the COVID-19 pandemic, each of the 53 students of dietetics made 8 PKU sandwiches for patients with phenylketonuria, totaling 424 PKU sandwiches. The majority of the sandwiches were appropriate for patients with PKU and presented in an attractive manner, thus being eligible for publication in the Album. Restrictive in terms of allowed ingredients, PKU sandwiches must not contain eggs and dairy products, meat, fish, cold cuts, nuts, grains, and legumes [15]. The list of permissible ingredients includes for example vegetables, fruits, substitutes for low protein products, vegetable oils and sugars. Although, due to the limited assortment of allowed products, many of the PKU sandwiches shared the same ingredients, the additions used, the variety of production methods, and presentation on the $21 \mathrm{~cm}$ plate were diversified to such an extent that only few sandwiches, since bearing a close resemblance to their counterparts, were not featured in the PKU Sandwiches Album.

The intention of the Album is to fulfill the basic idea of dietary education: to teach patients that they can use the same ingredients to make their own sandwiches, varying in form and taste. Thanks to the student's work, the Album will provide patients with PKU with both ready-made, balanced recipes for varied fruit or vegetable sandwiches that can be made "in $3 \mathrm{~min}$ " and more time-consuming sandwiches that will require them to make, for example, vegetable spread. The PKU Sandwiches Album is expected to inspire patients as well as caretakers or parents and help them add appeal to their diet, enriching it-by means of simple visualization - with new tastes, at the same time facilitating the memorizing process of ingredients and motivating them to comply with strict dietary recommendations. In addition, the PKU Sandwiches Album is to free patients with PKU from complicated calculations.

\section{The Results of Students' Work}

The students were tasked with preparing the PKU sandwiches based on Phenylalanine exchanger systems, where $1 \mathrm{PheE}$ it is the amount of food which contains $15 \mathrm{mg}$ phenylalanine (Phe). Phe exchangers are in use in some regions in Poland, especially in the 
region of Lower Silesia and the Opolskie Voivodeship. The sandwiches prepared by the students contained between 1 and 4 PheE ( $15 \mathrm{mg}, 22.5 \mathrm{mg}, 30 \mathrm{mg}, 37.5 \mathrm{mg}, 45 \mathrm{mg}, 52.5 \mathrm{mg}$ or $60 \mathrm{mg}$ of Phe, respectively). The innovative form of presenting the balance of sandwiches consists of performing separate calculations of nutritional values solely of the ingredients of a sandwich, excluding bread. It was intentional inasmuch as PKU patients are supposed to prepare sandwiches with their favorite low protein or self-baked bread, while the students were expected to try low-protein bread and analyze its assortment available on the Polish food market. Furthermore, each student presented their PKU sandwiches in a picture (top view) on a plate measuring $21 \mathrm{~cm}$ in diameter which was crucial in helping to determine the size of the portion. Table 1 presents types of PKU bread available in the market in Poland along with information on their nutritional values.

Table 1. Types of low-protein bread PKU and their nutritional value selected by dietetics students.

\begin{tabular}{|c|c|c|c|c|c|c|c|}
\hline Producer & The Name of the Bread PKU & $\begin{array}{c}\text { Energy } \\
\text { Value } \\
\text { (kcal/100 g) }\end{array}$ & $\begin{array}{c}\text { Phe } \\
\text { Content } \\
(\mathrm{mg} / 100 \mathrm{~g})\end{array}$ & $\begin{array}{c}\text { Protein } \\
\text { Content } \\
(\mathrm{g} / 100)\end{array}$ & $\begin{array}{l}\text { Fat Content } \\
(\mathrm{g} / 100 \mathrm{~g})\end{array}$ & $\begin{array}{c}\text { Carbohydrates } \\
\text { Content (g/100 } \\
\text { g) }\end{array}$ & $\begin{array}{c}\text { How Many } \\
\text { Slices Are There } \\
\text { in the PKU } \\
\text { Bread? }\end{array}$ \\
\hline \multirow{3}{*}{$\frac{\sqrt[5]{ \pm}}{\frac{5}{5}}$} & $\begin{array}{l}\text { Low protein bead “Chlebuś" PKU } \\
\text { ( } 250 \mathrm{~g})\end{array}$ & 289 & 22.5 & 1.97 & 8.1 & 59.6 & 14 \\
\hline & $\begin{array}{l}\text { Homemade low protein bread PKU } \\
\qquad(300 \mathrm{~g})\end{array}$ & 251 & 12.3 & 0.58 & 4.3 & 49.0 & $8-9$ \\
\hline & Low protein daily bread PKU $(300 \mathrm{~g})$ & 271 & 12.3 & 0.62 & 4.5 & 56.0 & $15-16$ \\
\hline \multirow{3}{*}{ 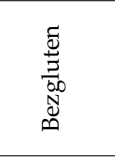 } & $\begin{array}{l}\text { Low protein sliced white bread PKU } \\
\qquad(320 \mathrm{~g})\end{array}$ & 263 & 20.0 & 0.5 & 6.5 & 47.0 & 10 \\
\hline & Low protein daily bread PKU (300 g) & 258 & 29.0 & 1.0 & 4.2 & 52.0 & 10 \\
\hline & $\begin{array}{l}\text { Low protein noble white bread PKU } \\
\qquad(200 \mathrm{~g})\end{array}$ & 262 & 20.0 & 0.5 & 6.5 & 47.0 & 9 \\
\hline \multirow{6}{*}{ 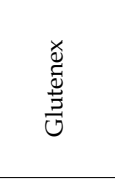 } & Loaf bread low protein $(250 \mathrm{~g})$ & 233 & 20.5 & 0.4 & 3.5 & 49.0 & ca. $10-12$ \\
\hline & Dark loaf bread low protein $(250 \mathrm{~g})$ & 238 & 23.0 & 0.4 & 3.5 & 50.0 & ca. $10-12$ \\
\hline & Buckwheat bread low protein (350 g) & 301 & 49.0 & 0.9 & 3.7 & 65.0 & ca. 15 \\
\hline & Sandwich bread low protein (400 g) & 297 & 26.0 & 0.5 & 4.5 & 62.0 & ca. 30 \\
\hline & Corn bread low protein $(400 \mathrm{~g})$ & 256 & 26.0 & 0.5 & 4.0 & 53.0 & ca. 30 \\
\hline & Crispbread low protein (100 g) & 398 & 42.0 & 0.8 & 3.4 & 91.0 & ca. $10-12$ \\
\hline \multirow{3}{*}{$\frac{. \pi}{\frac{\pi}{\pi}}$} & $\begin{array}{l}\text { Pan Carré, low protein white slice } \\
\text { bread }(2 \times 200 \mathrm{~g})\end{array}$ & 215 & 15.0 & 0.4 & 3.4 & 39.0 & 20 \\
\hline & $\begin{array}{l}\text { Pan Rustico, low protein brown sliced } \\
\text { bread ( } 400 \mathrm{~g})\end{array}$ & 218 & 30.0 & 0.8 & 3.8 & 37.0 & 20 \\
\hline & $\begin{array}{l}\text { Pane Casereccio, low protein sliced } \\
\text { bread }(220 \mathrm{~g})\end{array}$ & 214 & 20.0 & 0.6 & 3.8 & 38.0 & 5 \\
\hline
\end{tabular}

PKU—phenylketonuria, Phe-phenylalanine.

\section{The Educational and Practical Part of PKU Online Classes}

The educational and practical part of PKU classes consist of:

1. Designing PKU sandwiches.

2. Researching PKU products, particularly low protein bread, on the Internet and purchasing them.

3. Balancing the PKU sandwiches in a dietetic program.

4. Preparing PKU sandwiches.

5. Photographing the PKU sandwiches on a plate measuring $21 \mathrm{~cm}$ in diameter (photo in projection as a top view).

6. Sampling of the PKU sandwiches by students themselves or treating their family members to them.

7. The students presenting and discussing with the class and teachers their ideas for PKU sandwiches during online classes.

We assessed the PKU sandwiches in terms of their nutritional value (the caloric value, the amount the protein, fat and carbohydrates content), aesthetics, innovativeness and compliance with PKU diet guidelines (e.g., the amount of the Phe content).

Table 2 presents a selection of 12 PKU sandwiches prepared by the students. PKU sandwiches made by dietetics students were selected separately by us-academic teachers (doctor and dietitian). In the current publication we tried to present PKU sandwiches with 
a different composition, form, difficulty level, with different Phe content and caloric value, use of spices, presentation on a plate, accuracy of made and innovation.

Table 2. Selected PKU sandwiches presented by the students of dietetics during online lessons in diet-therapy of metabolic blocks (low-protein bread was not taken into account when calculating the nutritional value of PKU sandwiches and their Phe and PheE content).

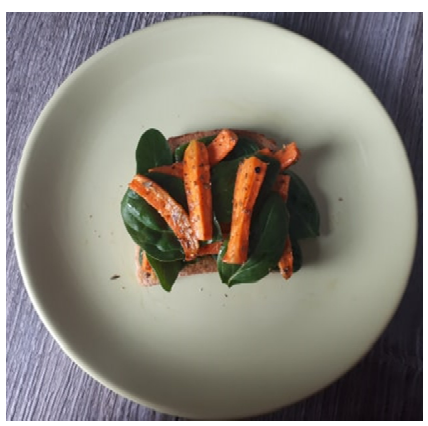

42 g carrots

With baked carrots and spinach

$5 \mathrm{~g}$ fresh spinach

10 g olive oil

a pinch of salt and pepper

Slice carrots into sticks, mix with olive oil and season. Bake in the oven for $20 \mathrm{~min}$ at $180^{\circ} \mathrm{C}$. Toast the bread. Place baked carrots and spinach on the toast.

\begin{tabular}{cccccc}
\hline PheE & Phe & Protein & Carbs & Fat & Calories \\
\hline & & & & & \\
1.5 & $22.5 \mathrm{mg}$ & $0.6 \mathrm{~g}$ & $3.8 \mathrm{~g}$ & $10.1 \mathrm{~g}$ & $105 \mathrm{kcal}$
\end{tabular}

Author: Sandra Piech

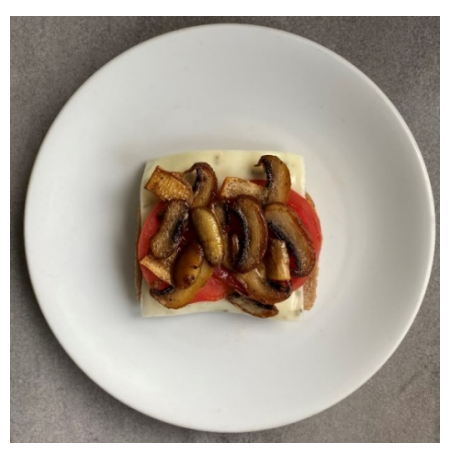

Author: Agnieszka Skwarek

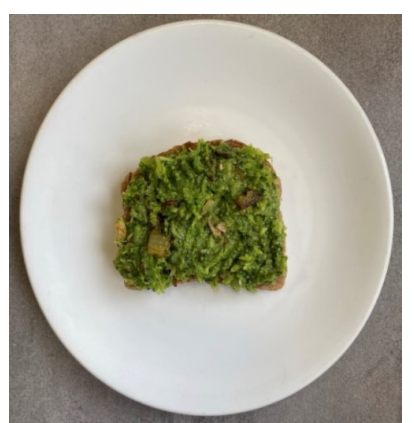

Author: Agnieszka Skwarek

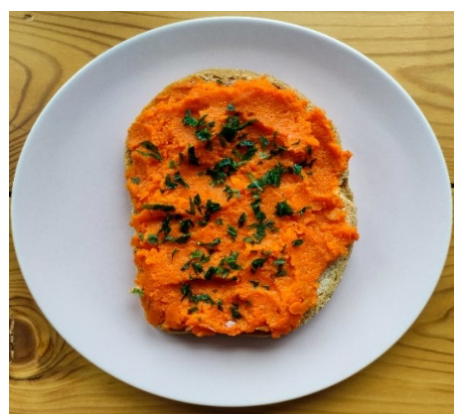

Author: Dominika Popiacka

\section{Toast with crispy mushrooms}

$20 \mathrm{~g}$ low protein vegan cheese (Violife smoked provolone cheese slices)

$22 \mathrm{~g}$ champignons

$34 \mathrm{~g}$ tomato

$10 \mathrm{~g}$ olive oil

a pinch of salt

Toast slices of bread in a dry frying pan (without oil). Slice mushrooms, season them with salt and fry in olive oil.

Top the PKU toast with low protein vegan cheese, tomato and pan-fried mushrooms.

\begin{tabular}{cccccc}
\hline PheE & Phe & Protein & Carbs & Fat & Calories \\
\hline 2.5 & $37.4 \mathrm{mg}$ & $0.9 \mathrm{~g}$ & $6.0 \mathrm{~g}$ & $14.6 \mathrm{~g}$ & $160 \mathrm{kcal}$
\end{tabular}

$38 \mathrm{~g}$ fresh broccoli

Broccoli spread sandwich

$9 \mathrm{~g}$ onion

5 g olive oil

a pinch of salt

Fry the finely diced onion in olive oil. Cook broccoli until very soft and mash it with a fork or blender. Add fried onions and spices.

\begin{tabular}{cccccc}
\hline PheE & Phe & Protein & Carbs & Fat & Calories \\
\hline 3.5 & $52.7 \mathrm{mg}$ & $1.3 \mathrm{~g}$ & $2.6 \mathrm{~g}$ & $5.2 \mathrm{~g}$ & $60 \mathrm{kcal}$
\end{tabular}

59 g carrots

Carrot spread sandwich

5 g garlic

$20 \mathrm{~g}$ onion

$3 \mathrm{~g}$ chopped parsley

5 g olive oil

Cook carrots until tender and cool.

Chop onion and garlic. Blend all ingredients, except parsley, to a smooth paste. Spread the paste on the bread and sprinkle it with chopped parsley.

\begin{tabular}{cccccc}
\hline PheE & Phe & Protein & Carbs & Fat & Calories \\
\hline 3.5 & $52.6 \mathrm{mg}$ & $1.3 \mathrm{~g}$ & $8.4 \mathrm{~g}$ & $5.2 \mathrm{~g}$ & $80 \mathrm{kcal}$
\end{tabular}


Table 2. Cont.

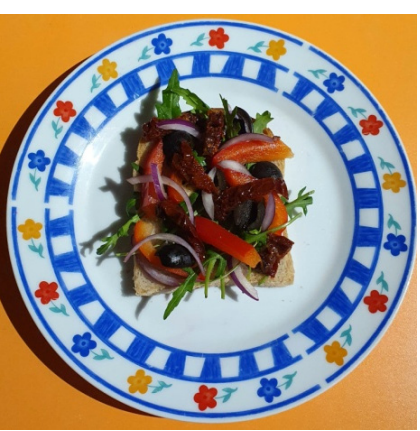

Author: Iryna Poshtar

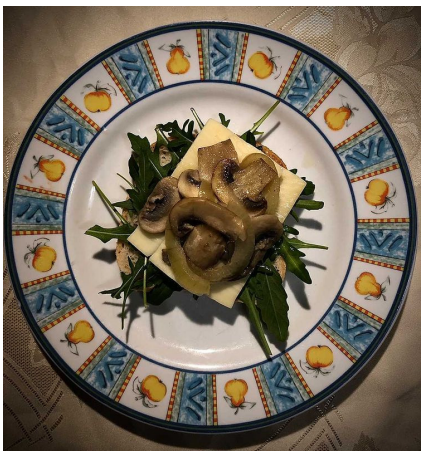

Author: Anna Sarnecka

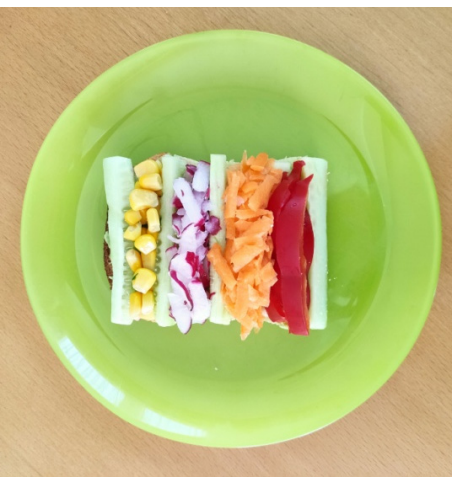

Author: Nela Boczar

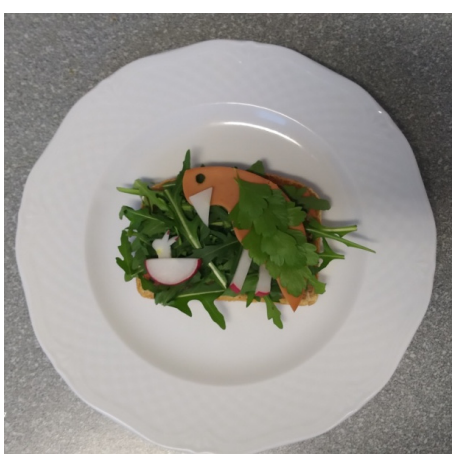

Author: Kamil Kalinowski

$5 \mathrm{~g}$ red onion

Sandwich with sun dried tomatoes and olives

$8 \mathrm{~g}$ pickled olives, canned

$14 \mathrm{~g}$ red pepper

$4 \mathrm{~g}$ arugula

$8 \mathrm{~g}$ dried tomatoes

$5 \mathrm{~g}$ olive oil

a pinch of salt and pepper

Brush a slice of PKU bread with olive oil. Top it with arugula and chopped vegetables: red bell pepper, olives, sun-dried tomatoes, and onion. Season to taste with salt and pepper.

\begin{tabular}{cccccc}
\hline PheE & Phe & Protein & Carbs & Fat & Calories \\
\hline 2.0 & $29.7 \mathrm{mg}$ & $0.8 \mathrm{~g}$ & $3.5 \mathrm{~g}$ & $7.2 \mathrm{~g}$ & $80 \mathrm{kcal}$ \\
\hline
\end{tabular}

$10 \mathrm{~g}$ arugula

Mushrooms on a pillow

$21 \mathrm{~g}$ mushrooms

$8 \mathrm{~g}$ onion

$30 \mathrm{~g}$ low protein vegan cheese (Violife smoked provolone cheese slices)

$6 \mathrm{~g}$ margarine

5 g canola oil

Fry mushrooms and onions in oil. Spread PKU bread with margarine, top with arugula, sliced vegan cheese, mushrooms and onions.

\begin{tabular}{cccccc}
\hline PheE & Phe & Protein & Carbs & Fat & Calories \\
\hline 3.0 & $45.2 \mathrm{mg}$ & $0.8 \mathrm{~g}$ & $7.2 \mathrm{~g}$ & $14.6 \mathrm{~g}$ & $167 \mathrm{kcal}$
\end{tabular}

\section{Colorful PKU sandwich}

$17 \mathrm{~g}$ avocado

$9 \mathrm{~g}$ canned corn

22 g carrots

$33 \mathrm{~g}$ cucumber

$15 \mathrm{~g}$ red pepper

$15 \mathrm{~g}$ radish

Mash avocado with a fork and spread on the slice of PKU bread. Top with corn, grated radish, carrot and sliced bell pepper (separate vegetable layers with peeled cucumber strips).

\begin{tabular}{cccccc}
\hline PheE & Phe & Protein & Carbs & Fat & Calories \\
\hline 3.5 & $52.4 \mathrm{mg}$ & $1.4 \mathrm{~g}$ & $7.9 \mathrm{~g}$ & $2.9 \mathrm{~g}$ & $59 \mathrm{kcal}$
\end{tabular}

$5 \mathrm{~g}$ arugula

"Bird mom" sandwich

$7 \mathrm{~g}$ low protein vegan cheese (Violife cheddar flavor slices)

2 g parsley

$9 \mathrm{~g}$ radish

$3 \mathrm{~g}$ olive oil

Drizzle the slice of PKU bread with olive oil. Cut shapes out of vegan cheese slices (bird) and radish (chick, beak, legs). Place them on the bread and top with arugula. Add parsley to create the bird's feathers.

\begin{tabular}{cccccc}
\hline PheE & Phe & Protein & Carbs & Fat & Calories \\
\hline 1.0 & $15.0 \mathrm{mg}$ & $0.3 \mathrm{~g}$ & $2.0 \mathrm{~g}$ & $4.6 \mathrm{~g}$ & $52 \mathrm{kcal}$
\end{tabular}


Table 2. Cont.

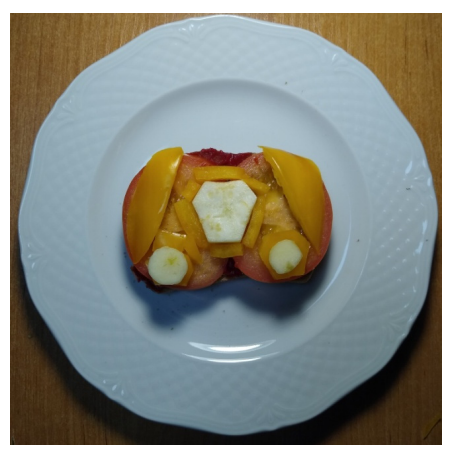

$50 \mathrm{~g}$ tomato

"IronMan" sandwich

Author: Katarzyna Kała

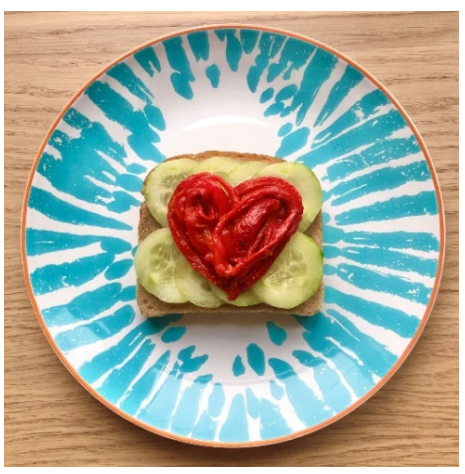

$39 \mathrm{~g}$ cucumber

45 g yellow pepper

$20 \mathrm{~g}$ zucchini

$5 \mathrm{~g}$ tomato concentrate

Spread the slice of the PKU bread with tomato concentrate. Top the bread with tomato slices. Arrange slices of zucchini and peppers on tomatoes to create "armor".

\begin{tabular}{cccccc}
\hline PheE & Phe & Protein & Carbs & Fat & Calories \\
\hline & & & & & \\
3.0 & $44.8 \mathrm{mg}$ & $1.4 \mathrm{~g}$ & $6.4 \mathrm{~g}$ & $0.3 \mathrm{~g}$ & $30 \mathrm{kcal}$
\end{tabular}

$20 \mathrm{~g}$ canned red peppers

5 g olive oil

Peel the cucumber and cut it into slices. Cut the canned red peppers into oblong strips.

Drizzle the PKU bread with olive oil, top with cucumber. Arrange peppers in the shape of a heart.

\begin{tabular}{cccccc}
\hline PheE & Phe & Protein & Carbs & Fat & Calories \\
\hline
\end{tabular}

$\begin{array}{llllll}1.0 & 15.0 \mathrm{mg} & 0.4 \mathrm{~g} & 2.1 \mathrm{~g} & 5.3 \mathrm{~g} & 57 \mathrm{kcal}\end{array}$

Author: Bhakti Mallick

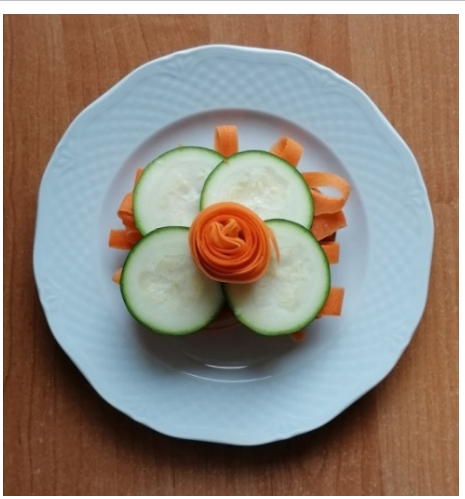

50 g zucchini

Carrot and zucchini sandwich

Author: Aleksandra Batiuk

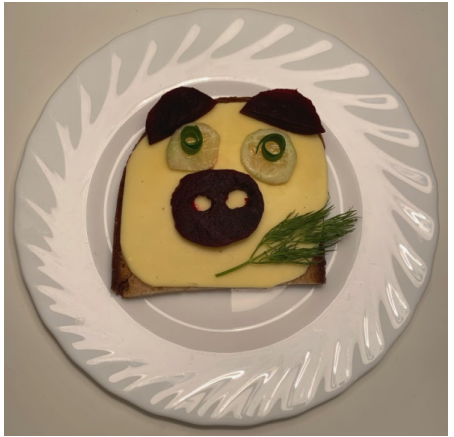

Author: Weronika Cygan

50 g carrots

$10 \mathrm{~g}$ canola oil

Peel and cut the carrots into strips. Cut zucchini into slices. Drizzle them with vegetables with canola oil and arrange on the sandwich according to a given pattern.

\begin{tabular}{cccccc}
\hline PheE & Phe & Protein & Carbs & Fat & Calories \\
\hline & & & & & \\
& & & & & \\
3.0 & $45.0 \mathrm{mg}$ & $1.1 \mathrm{~g}$ & $6.0 \mathrm{~g}$ & $10.2 \mathrm{~g}$ & $116 \mathrm{kcal}$
\end{tabular}

"A little pig" sandwich

$12 \mathrm{~g}$ cooked beet

$5 \mathrm{~g}$ cucumber

$1 \mathrm{~g}$ dill

$1 \mathrm{~g}$ chives

$20 \mathrm{~g}$ low protein vegan cheese (Violife smoked provolone cheese slices)

$5 \mathrm{~g}$ cream butter

Butter the bread and top it with a slice of cheese (round the corners to obtain a piggy face effect). Cut out pieces from the beet and cucumber (as shown in the photo) and place them on the cheese. To obtain the "ribbon" effect, cut the chives in half and it will curl up like this. Garnish the PKU sandwich with dill leaves.

\begin{tabular}{cccccc}
\hline PheE & Phe & Protein & Carbs & Fat & Calories \\
\hline 1.5 & $22.5 \mathrm{mg}$ & $0.4 \mathrm{~g}$ & $5.4 \mathrm{~g}$ & $8.7 \mathrm{~g}$ & $103 \mathrm{kcal}$
\end{tabular}

PheE-phenylalanine exchanger, Phe-phenylalanine, Carbs-Carbohydrates. Students agreed to publish PKU sandwiches from online classes in the publication. 
In order to balance their PKU sandwiches, especially when taking into consideration their Phe content, the students used Polish dietetic programs using mainly the Polish tables of contents and caloric value of groceries for reference [13].

\section{Discussion}

Phenylketonuria is a rare metabolic disorder caused by mutations of the gene coding the enzyme phenylalanine hydroxylase (PAH) [16]. The deficiency of PAH results in the accumulation of phenylalanine in blood and the brain, which-if undiagnosed and untreated-gradually impairs the metabolism and cognitive development, leading to neuropsychological and behavioral disorders, eventually damaging the nervous system and resulting in intellectual disability $[17,18]$. Starting treatment by implementing a lowphenylalanine diet early in the neonatal period and maintaining it for a patient's life helps reduce the risk of symptom manifestation. The basic dietary treatment of PKU is founded on strict control of natural Phe intake from foods according to individual Phe tolerance using food for special medical purposes (FSMPs) and low protein products such as bread, pasta, cheese, milk, etc. Keeping a PKU diet for the entire duration of treatment proves to be a significant challenge and burden for patients, particularly in adulthood and adolescence [19]. A PKU diet might also constitute a major obstacle in patients' establishment of meaningful social relationships [20]. However, certain patients with PKU (mainly with a mild form of PKU) are responsive to treated with cofactor tetrahydrobiopterin (BH4) [16,21,22], but till now not refunded in Poland. Since the majority of Polish PKU patients suffer from a classic type of PKU characterized by a very low Phe tolerance, i.e., 200-250 mg Phe/day, a monitored intake of Phe-sourced from fruits and vegetables-is advisable.

However, current recommendations of the European Society of Phenylketonuria and Allied Disorder (ESPKU) in a PKU diet allows the consumption of fruits and vegetables that contain less than $75 \mathrm{mg}$ of phenylalanine per $100 \mathrm{~g}$ without Phe measurement [15]. This refers to all fruits and vegetables for which 1 Phe exchanger is greater than $20 \mathrm{~g}$. Contrary to Europe, in dietary treatment in PKU in the US, Phe calculation in whole diet is recommended. Recently, some tendency to use the Simplified Diet, but not to liberalize it has been observed [23]. Not long ago, in the US this trend was not recommended to pregnant women and children under 2 years of age, because no data were published on the degree of metabolic control attained with the Simplified Diet in those groups. In the research by Hansen et al. [23], 46\% of respondents indicated that the lack of educational materials was barrier to the use of the Simplified Diet. The PKU Sandwiches Album that we offer is the first step to the simplified PKU diet.

As scientific papers concerning both the dietary education of PKU patients and students of dietetics, who in the future are supposed to assist patients with PKU in dietkeeping [24], remain scarce, patients are often aware and well-informed of their disease. What they lack, though, is the motivation to try new PKU meals and make their meals more attractive. Rohde C. et al. [25] have demonstrated that patients with PKU who do not comply with all dietary recommendations do not obtain enough nutrients from their diet, which in consequence may lead to nutritional insufficiency. Cazzorla C. et al. [26] concluded that an average concentration of Phe in 17 adult patients (aged 17-35) on a PKU diet was above the recommended upper limit of the norm, according to the recommendation applicable in Italy on the day of the test $(826 \pm 261 \mu \mathrm{mol} / \mathrm{L})$ and for the period of subsequent 12 months $(777 \pm 240 \mu \mathrm{mol} / \mathrm{L})$. Patients with classic PKU, conscious of the necessity to keep their diet for life, find it problematic to follow the guidelines.

There is scientific evidence that as patients grow older, they find it more difficult to maintain a recommended Phe concentration, even though the upper safety limit of Phe concentration for patients aged 12 is from 360 to $600 \mu \mathrm{mol} / \mathrm{L}$, according to data gathered all across Europe [16]. In 2014, however, representatives of the American College of Medical Genetics and Genomics updated the recommendations for all PKU patients to maintain the concentration of Phe on the level of 120-360 $\mu \mathrm{mol} / \mathrm{L}$ [27]. On the basis of online surveys 
conducted in 44 clinics in the USA, Jurecki et al. [28] concluded that in the majority of patients with PKU the concentration of Phe in blood was above $360 \mu \mathrm{mol} / \mathrm{L}$, and even in $15 \%$ of patients aged $18-29$ and in $20 \%$ of patients above the age of 30 the concentration of Phe in blood was $>1200 \mu \mathrm{mol} / \mathrm{L}$. The ACMG recommends that patients with PKU frequently monitor the concentration of Phe in their blood to achieve optimal treatment results. Another study found that both adult and younger PKU patients reported difficulties in keeping a PKU diet and complained that their diet therapy renders the performance of everyday activities challenging $[20,29,30]$.

\section{Implications for Research and Practice}

From scientific papers on PKU, it emerges that dietitians and doctors treating rare metabolic diseases are currently exploring solutions that would help their patients better keep and monitor their diets. Providing patients with a list of allowed and prohibited products along with information on the allowed amount of Phe in their diet is insufficient in terms of motivating them to observe the recommendations. Patients should be provided with ready-made tools, algorithms and pragmatic ideas, which would considerably increase their quality of life. The awareness of this necessity led to the development, in cooperation with the students of dietetics, of the PKU Sandwiches Album. The PKU Sandwiches Album will be published by Lower Silesian Friends Association for Children with Phenylketonuria and distributed to patients directly by the doctor in the metabolic clinic, in the region of Lower Silesia and the Opolskie Voivodeship in Poland. The circulation will be approximately 2000 copies and patients from other parts of Poland will also be able to obtain it for free. Depending on the interest, pdf versions will also be considered.

It is worth mentioning that many educational activities as well as educational-health programs were suspended during the COVID-19 pandemic [31]. In these circumstances, a new approach to food education, both of the healthy and the sick, in the form of consultations, online meeting, remote training and workshops, is required. In conclusion, the problem of PKU patients not maintaining the optimal concentration of Phe is a global one, which is why patients, dietitians and doctors should be equipped with additional educational aids to tackle it more effectively. The food education of PKU patients should be continuous and highlighting predominantly its pragmatic aspect.

There are scientific studies showing discrepancies between the views of clinicians and patients about the perceived effectiveness of nutritional education tools in PKU. Therefore, it would be advisable to extend the research to include the effectiveness of using the PKU Sandwiches Album on improving dietary adherence in PKU patients, as it is a new educational tool and has not yet been evaluated.

\section{Conclusions}

Students are more motivated to perform a task if they know that their work (in this case-a metabolic meal), will be published. The competition between them makes them come up with new solutions in creating PKU sandwiches even using the same products, which is important in a low protein diet where the amount of permitted ingredients is significantly limited to high protein products. Lockdown during the COVID-19 pandemic and the ensuing transition to remote work demanded that students work individually. Moreover, by conducting well-planned remote exercises with students (also during COVID19), academic teachers are capable of achieving numerous goals— the goal determined by the author of the paper was developing the PKU Sandwiches Album.

Presented in the form of a caloric balance of the used ingredients, the Album may be used for the purpose of planning other diets (low cholesterol, lactose-free, low calorie or gluten-free), taking into account other types of bread, e.g., low GI, plain, gluten-free. It highlights a bonding property of the Album, demonstrating that PKU patients are not the only people following a strict dietary regimen. What is more, the fact that patients know that their PKU Sandwiches Album can be used by others, not only those suffering from PKU, may have a positive impact on a better acceptance of their diet. 
Presenting on the plate, a balanced meal in terms of its content of Phe may have a beneficial effect on patients' compliance and result in their easier understanding of a PKU diet.

The presented idea of conducting classes with students and creating with their help a practical tool for educating patients with PKU and their caretakers/parents may in the future be used by a large group of academic teachers, doctors and nutritionists to improve the quality of life of patients not only with PKU but also in other rare metabolic disorders, which require dietary treatment. More research is required to assess the effectiveness of using the PKU Sandwiches Album on improving dietary adherence in PKU patients.

Author Contributions: Conceptualization, K.K. and R.M.; validation, K.K. and R.M.; investigation, K.K. and R.M.; resources, K.K. and R.M.; writing-original draft preparation, K.K. and R.M.; supervision, R.M. All authors have read and agreed to the published version of the manuscript.

Funding: This research received no external funding.

Institutional Review Board Statement: Not applicable.

Informed Consent Statement: Not applicable.

Data Availability Statement: The datasets used during the current study are available from the corresponding author upon reasonable request.

Acknowledgments: Katarzyna Bednarz from Lower Silesian Friends Association for Children with Phenylketonuria for her efforts to release the PKU Sandwiches Album.

Conflicts of Interest: The authors declare no conflict of interest.

\section{References}

1. Acosta, P.B.; Fiedler, J.L.; Koch, R. Mothers' dietary management of PKU children. J. Am. Diet. Assoc. 1968, 53, 460-464. [CrossRef]

2. Acosta, P.B.; Wenz, E.; Williamson, M. Methods of dietary inception in infants with PKU. J. Am. Diet. Assoc. 1978, 72, 164-169. [CrossRef]

3. Schuett, V.E. Low Protein Cookery for PKU, 3rd ed.; The University of Wisconsin Press: Madison, WI, USA, 1997; ISBN 9780299153847.

4. Mozrzymas, R.; Żółkowska, J.; Marczyk, T.; Andrysiak, A.; Czekajło, A. A Diet Like a Fairy Tale—Low-Phenylalanine Diet [Dieta jak z Bajki-Dieta Niskofenyloalaninowa]; Renata Mozrzymas: Wrocław, Poland, 2015; ISBN 978-83-941729-0-9. (In Polish)

5. Ahring, K.; Bélanger-Quintana, A.; Dokoupil, K.; Gokmen Ozel, H.; Lammardo, A.M.; MacDonald, A.; Motzfeldt, K.; Nowacka, M.; Robert, M.; van Rijn, M. Dietary management practices in phenylketonuria across European centres. Clin. Nutr. 2009, 28, 231-236. [CrossRef] [PubMed]

6. Bekhof, J.; van Spronsen, F.J.; Crone, M.R.; van Rijn, M.; Oudshoorn, C.G.; Verkerk, P.H. Influence of knowledge of the disease on metabolic control in phenylketonuria. Eur. J. Pediatr. 2003, 162, 440-442. [CrossRef] [PubMed]

7. Singh, R.H.; Rohr, F.; Frazier, D.; Cunningham, A.; Mofidi, S.; Ogata, B.; Splett, P.L.; Moseley, K.; Huntington, K.; Acosta, P.B.; et al. Recommendations for the nutrition management of phenylalanine hydroxylase deficiency. Genet. Med. 2014, 16, 121-131. [CrossRef] [PubMed]

8. Ozel, H.G.; Kucukkasap, T.; Koksal, G.; Sivri, H.S.; Dursun, A.; Tokatli, A.; Coskun, T. Does maternal knowledge impact blood phenylalanine concentration in Turkish children with phenylketonuria? J. Inherit. Metab. Dis. 2008, 31 (Suppl. 2), S213-S217. [CrossRef] [PubMed]

9. Durham-Shearer, S.J.; Judd, P.A.; Whelan, K.; Thomas, J.E. Knowledge, compliance and serum phenylalanine concentrations in adolescents and adults with phenylketonuria and the effect of a patient-focused educational resource. J. Hum. Nutr. Diet. 2008, 21, 474-485. [CrossRef]

10. MacDonald, A.; Davies, P.; Daly, A.; Hopkins, V.; Hall, S.K.; Asplin, D.; Hendriksz, C.; Chakrapani, A. Does maternal knowledge and parent education affect blood phenylalanine control in phenylketonuria? J. Hum. Nutr. Diet. 2008, 21, 351-358. [CrossRef]

11. Witalis, E.; Mikoluc, B.; Motkowski, R.; Sawicka-Powierza, J.; Chrobot, A.; Didycz, B.; Lange, A.; Mozrzymas, R.; Milanowski, A.; Nowacka, M.; et al. Phenylketonuria patients' and their parents' knowledge and attitudes to the daily diet-multi-centre study. Nutr. Metab. 2017, 14, 57. [CrossRef]

12. DietetykPro. Available online: https:/ / dietetykpro.pl/ (accessed on 10 February 2022).

13. Kunachowicz, H.; Przygoda, B.; Nadolna, I.; Iwanow, K. Food Composition Table [Tabele Składu i Wartości Odżywczej Żywności], 2nd ed.; PZWL: Warszawa, Poland, 2017. (In Polish)

14. FoodData Central, U.S. Department of Agriculture. Available online: https://fdc.nal.usda.gov/fdc-app.html\#/ (accessed on 10 February 2022). 
15. MacDonald, A.; van Wegberg, A.M.J.; Ahring, K.; Beblo, S.; Bélanger-Quintana, A.; Burlina, A.; Campistol, J.; Coşkun, T.; Feillet, F.; Giżewska, M.; et al. PKU dietary handbook to accompany PKU guidelines. Orphanet J. Rare Dis. 2020, 15, 171. [CrossRef]

16. Van Wegberg, A.M.J.; MacDonald, A.; Ahring, K.; Bélanger-Quintana, A.; Blau, N.; Bosch, A.M.; Burlina, A.; Campistol, J.; Feillet, F.; Giżewska, M.; et al. The complete European guidelines on phenylketonuria: Diagnosis and treatment. Orphanet J. Rare Dis. 2017, 12, 162. [CrossRef] [PubMed]

17. Blau, N.; van Spronsen, F.J.; Levy, H.L. Phenylketonuria. Lancet 2010, 376, 1417-1427. [CrossRef]

18. Feillet, F.; van Spronsen, F.J.; MacDonald, A.; Trefz, F.K.; Demirkol, M.; Giovannini, M.; Bélanger-Quintana, A.; Blau, N. Challenges and pitfalls in the management of phenylketonuria. Pediatrics 2010, 126, 333-341. [CrossRef] [PubMed]

19. MacDonald, A.; Gokmen-Ozel, H.; van Rijn, M.; Burgard, P. The reality of dietary compliance in the management of phenylketonuria. J. Inherit. Metab. Dis. 2010, 33, 665-670. [CrossRef]

20. Cazzorla, C.; Del Rizzo, M.; Burgard, P.; Zanco, C.; Bordugo, A.; Burlina, A.B.; Burlina, A.P. Application of the WHOQOL-100 for the assessment of quality life of adult patients with inherited metabolic diseases. Mol. Genet. Metab. 2012, 106, 25-30. [CrossRef]

21. Bik-Multanowski, M.; Kaluzny, L.; Mozrzymas, R.; Oltarzewski, M.; Starostecka, E.; Lange, A.; Didycz, B.; Gizewska, M.; Ulewicz-Filipowicz, J.; Chrobot, A.; et al. Molecular genetics of PKU in Poland and potential impact of mutations on BH4 responsiveness. Acta Biochim. Pol. 2013, 60, 613-616. [CrossRef]

22. Burlina, A.; Biasucci, G.; Carbone, M.T.; Cazzorla, C.; Paci, S.; Pochiero, F.; Spada, M.; Tummolo, A.; Zuvadelli, J.; Leuzzi, V. Italian national consensus statement on management and pharmacological treatment of phenylketonuria. Orphanet J. Rare Dis. 2021, 16, 476. [CrossRef]

23. Hansen, J.; Hollander, S.; Drilias, N.; Van Calcar, S.; Rohr, F.; Bernstein, L. Simplified Diet for nutrition management of phenylketonuria: A survey of U.S. metabolic dietitians. JIMD Rep. 2020, 53, 83-89. [CrossRef]

24. Crabill, D.; Kubota, J.; LaSalle, C. P154 Impact of Cooking Classes on Students' Knowledge and Ability to Make Culinary Recommendations for Low-Phe Diets. J. Nutr. Educ. Behav. 2020, 52, S89. [CrossRef]

25. Rohde, C.; von Teeffelen-Heithoff, A.; Thiele, A.G.; Arelin, M.; Mütze, U.; Kiener, C.; Gerloff, J.; Baerwald, C.; Schultz, S.; Heller C.; et al. PKU patients on a relaxed diet may be at risk for micronutrient deficiencies. Eur. J. Clin. Nutr. 2014, 68, 119-124. [CrossRef]

26. Cazzorla, C.; Cegolon, L.; Burlina, A.P.; Celato, A.; Massa, P.; Giordano, L.; Polo, G.; Daniele, A.; Salvatore, F.; Burlina, A.B. Quality of Life (QoL) assesment in a cohort of patients with phenylketonuria. BMC Public Health 2014, 14, 1243. [CrossRef]

27. Vockley, J.; Andersson, H.C.; Antshel, K.M.; Braverman, N.E.; Burton, B.K.; Frazier, D.M.; Mitchell, J.; Smith, W.E.; Thompson, B.H.; Berry, S.A.; et al. Phenylalanine hydroxylase deficiency: Diagnosis and management guideline. Genet. Med. 2014, 16, 188-200, Erratum in Genet. Med. 2014, 16, 356. [CrossRef] [PubMed]

28. Jurecki, E.R.; Cederbaum, S.; Kopesky, J.; Perry, K.; Rohr, F.; Sanchez-Valle, A.; Viau, K.S.; Sheinin, M.Y.; Cohen-Pfeffer, J.L. Adherence to clinic recommendations among patients with phenylketonuria in the United States. Mol. Genet. Metab. 2017, 120, 190-197. [CrossRef] [PubMed]

29. Enns, G.M.; Koch, R.; Brumm, V.; Blakely, E.; Suter, R.; Jurecki, E. Suboptimal outcomes in patients with PKU treated early with diet alone: Revisiting the evidence. Mol. Genet. Metab. 2010, 101, 99-109. [CrossRef] [PubMed]

30. Walter, J.H.; White, F.J.; Hall, S.K.; MacDonald, A.; Rylance, G.; Boneh, A.; Francis, D.E.; Shortland, G.J.; Schmidt, M.; Vail, A How practical are recommendations for dietary control in phenylketonuria? Lancet 2002, 360, 55-57. [CrossRef]

31. Haidar, A.; Khoei, A.; Alex, S.E.; Blick, C.; Lopez, E.; Wendt, S.; Ghanta, R.; Almohamad, M.; Cousins, S.; Noyola, J.; et al. Community-Academic Partnerships to Promote Health Literacy and Adress Social Needs Among Low-Income Families During COVID-19. J. Nutr. Educ. Behav. 2021, 53, 75-78. [CrossRef] [PubMed] 